\title{
THE QUANTIFICATION OF INCOME INEQUALITY IN SOCIETY IN THE CASE OF THE COUNTRIES OF THE EUROPEAN UNION
}

\author{
[Kvantifikace př́ijmové nerovnosti ve společnosti na př́íkladu zemí \\ Evropské unie]
}

\author{
Jolana Skaličková ${ }^{1}$ \\ ${ }^{1}$ Moravian Business College Olomouc, Tř. Kosmonauti̊ 1288/1, 77900 Olomouc \\ Email:jolana.skalickova@mvso.cz
}

\begin{abstract}
The paper focuses on the issue of income inequality, which is an integral part of currently developed economies. Accesses to mitigation provided by the government to a large extent by means of transfer payments may be different. The aim of this paper is to find out whether there are mutual links between selected indicators of income inequality and how they change after the inclusion of transfer payments. The data contains the following indicators: the Gini index before and after a transfer payment and the coefficient S80/S20. For the purposes of achieving the main objective of the paper, there is the correlation analysis uses. Based on the results there is very strong dependence between the Gini index and the coefficient S80/S20. Their ability to describe the system is almost the same. The relationship between these indicators of income inequality and the Gini index before transfer payments is only middle positive dependency because a transfer payment is different in more aspects.
\end{abstract}

Keywords: coefficient S80/S20, European Union, Gini index, income inequality, transfer payments.

JEL classification: D31

Received: 11.10.2018; Reviewed: 24.10.2018; 1.11.2018; Accepted: 6.3.2019

\section{Introduction}

The issue of inequality is the subject of discussion in many areas not only in contemporary society. From the economic point of view, income inequality is among the most significant inequalities. The conflict between equality and justice remains an unsolved issue even in the current democratic society. The economic levelling can, on the one hand, significantly rise the spending of public budgets. On the other hand, however, there is the danger of too great and unregulated socio-economic differences. Income inequality can be viewed as a natural characteristic of a functioning society; however, in the case of its extreme values, it is also necessary to take it into account as a possible obstacle to the economic development.

Income inequality must be perceived as a global problem. It can be stated that, in general, the global trend has brought income polarization to the state of huge concentrations of wealth belonging only to $5-7 \%$ of the population. This phenomenon is closely related to the issue of the living on credit which can be found in most of the developed countries, and therefore it is necessary to keep in mind the threat of poverty for the lowest income groups of the population resulting from the income stratification (more in Tiruneh et al. 2009).

The primary distribution of income is also largely influenced by the state. The state uses its economic policies to determine the income differences among its citizens. The area of fiscal policy is of great importance. It is this area, which, by setting the level of tax levies, regulates not only the revenue of the state budget, but can also reduce the gap between the available income of the population by implementing the redistribution function. The social policy is another vital area. The main role of this policy is the redistributive process which occurs especially via transfer payments. 
The aim of the presented article is to find out whether there are mutual links between selected indicators of income inequality and how they change after the inclusion of transfer payments. The relationships between selected indicators of income inequality of states in the European Union is analysed and the changes after the inclusion of transfer payment are described and investigated.

\section{Literature overview}

An analysis of income differentiation is an element of the methodology of a comprehensive perspective of the evolution of income polarization and the polarization of wealth in the global world (see Želinský, Pauhofová 2012). In order to be able to decide on the possible influence of this area, it is necessary to express its progress. Mathematical and statistical tools used for the clarification of individual parameters of income inequalities are associated with the study of their causes. The $20^{\text {th }}$ century has seen a gradual development of a series of tools serving this purpose. Among the tools most often used there are the Gini index and the S80/S20 Income Inequality Coefficient.

Many of the analyses have dealt with the relationship between income inequality and macroeconomic indicators. The results of the report of the International Labor Organization (2013) exploring the relationship between economic growth and employment in relation to income inequality on a sample of 24 selected African, Asian and South American countries have shown that there is an influence of employment growth on the reduction of income inequality. The influence of economic growth, however, has not been proved. The same result was shown by Kvíčalová (2014). When examining the relationship between the Gini index on one hand and unemployment, economic growth, inflation and debt on the other, the EU countries have shown a statistically significant dependence between the increase of income inequality and unemployment.

An interesting study was introduced by Večerník (2012) when comparing GDP and the satisfaction of the population in European countries. Večerník concluded that although satisfaction increases linearly with the level of GDP or income, the effects of these variables are weak. In some countries (e.g. in the Czech Republic) this satisfaction significantly correlated with levels of GDP, in others (e.g. France) no significant relationship has been found. Adrian Risso, Sanchez Carrera (2018) analysed the causality between GDP per capita, research and development, and income inequality. They said, that there is bidirectional causality between GDP per capita and R\&D, while R\&D causes the Gini index of income inequality.

The primary distribution of income is largely influenced by the states and their economic policy. The state can determine the income differences among its citizens. Fiscal policy and social policy are very important. The main role of social policy is the redistributive process which occurs especially via transfer payments. Hrdličková (2006) analyzed the development of tax quota, social transfers, as well as the distribution of taxes and benefits between income groups and the Gini index in the Czech Republic from the early 1990s until 2004. On the basis of this data, it was shown that there are high levels of redistribution, both on the side of those who contribute to the system, and on the side of drawing from the system. Malá and Červená (2012) confirmed the results of the analysis of income inequality of the years 2005 to 2009. The redistribution mechanisms greatly affect the compensation of income. Vítek and Pavel (2012) compared the importance of taxation and benefits system for income inequality in the Czech Republic on the example of the reforms which took place in the years 2005 to 2006 and 2008. Their results illustrated by the Lorenz curve and the Gini index show that the 
system of benefits brings about a much larger alteration of the income distribution than the tax system change. On the contrary Akbulut, Guran (2015) refute the influence of transfer payments on economic growth on the sample of developing countries. the role of the tax system and the social security systems in reducing income inequality in Croatia.

\section{Data and Methodology}

\subsection{Data}

The main data source used to analyse relationships between selected indicators of income inequality of states in the European Union is Eurostat. For the purposes of the correlation analysis, the following data are used: the coefficient S80/S20 income quintile share ratio, the Gini index of equivalised disposable income and the Gini index of equivalised disposable income before social transfers (pensions included in social transfers).

The disposable income of a household is calculated by adding together the personal income received by all of household members and income received at household level. Disposable household income includes all income from work, private income from investment and property, transfers between households and all social transfers received in cash including oldage pensions. It is the gross income information.

The selected indicators are part of a series of carried out analyses. E.g. Rochovská and Námešný (2011) used these indicators to analyse income inequality in Slovakia since 1993 to the year 2009. Atkinson, et al. (2010) used them for the study of poverty and inequality across countries of the European Union, Matsaganis and Leventi (2013) used them on the example of Greece affected by the fiscal crisis.

The time development of income inequalities is presented in graphical expression. Figure 1 shows the development of the Gini index in 7 selected countries of the European Union. These states have different value of income inequality in the figure. There are only 7 states due to clarity of the graphical presentation. The value of the Gini index ranges in the interval $\langle 0 ; 100\rangle$. While the value of 0 means an absolutely equal distribution of income in the society, the value of 100 means an absolutely unequal distribution of income.

In the Czech Republic, no significant deviations are observed and the situation of income inequality can be described as stable. It is located in the bottom part of the chart, which is more typical for an egalitarian situation. In a similar position, there is Finland (included in the comparison as a typical representative of the Scandinavian countries with a strong social state) and Slovakia, having a singular noticeable variation in 2014. Germany and France are in the middle of the chart (as representatives of the major European economies) Estonia and Latvia (belonging to the European countries with the highest inequality value) report a slight fluctuation of the index, the index decreases in Latvia but then again it increases in Estonia. 
Figure 1: Gini index time development

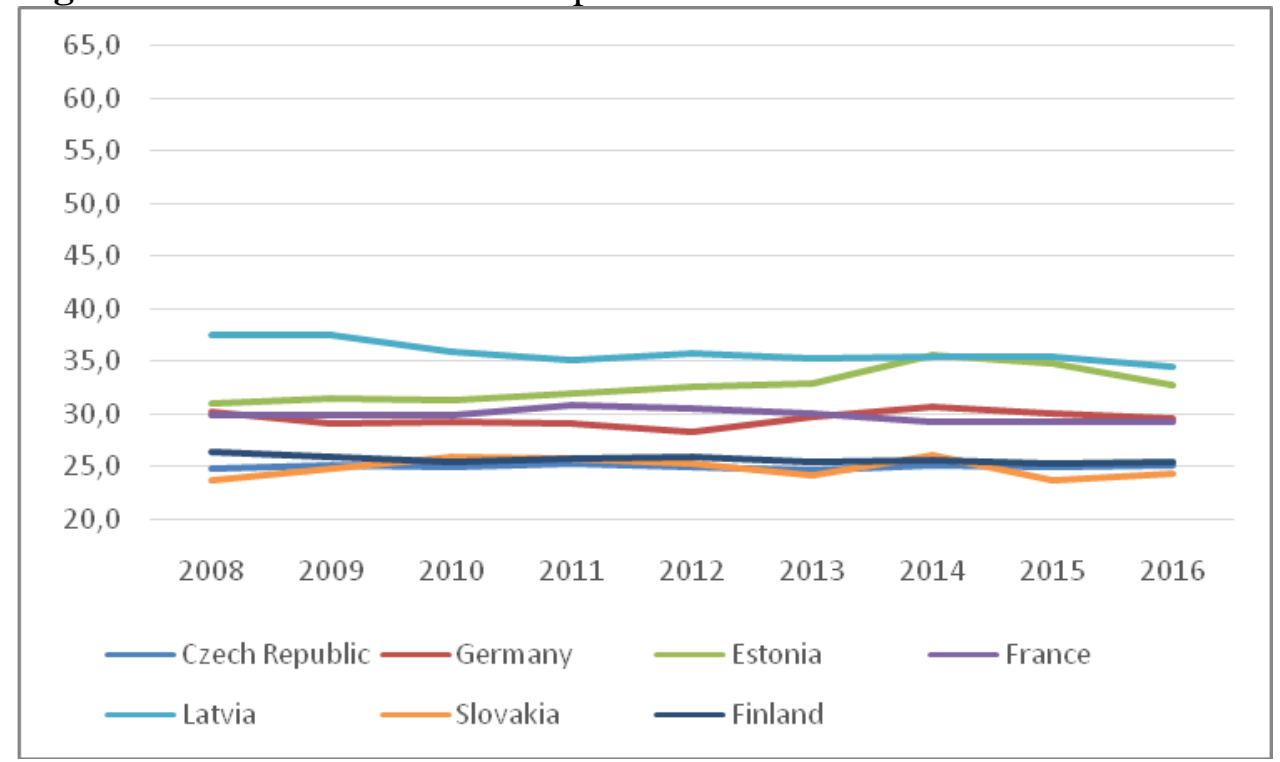

Source: Eurostat [online][ Accessed: 2018, July 30]. Available from < http://appsso.eurostat.ec.europa.eu/nui/show.do?dataset=ilc_di12>.

Figure 2 presents the development of the Gini index before a transfer payment in 7 selected countries of the European Union. We can see the highest values of the Gini index before a transfer payment in Germany. Germany was in the middle of the chart in the case of the Gini index in the previous figure. The change of the Gini index before and after a transfer payment says that there is a great influence on social policy in Germany. There are Latvia, France, Estonia, and Finland in the middle of the chart. The value of index slightly increases through a period in France and in Finland. Vice versa the value of index decreases in the end of the analysed period in Latvia and Estonia. The Czech Republic and Slovakia is situated in the bottom part of the chart. That is states with the lowest income inequality in the European Union.

Figure 2: Gini index before transfer payment time development

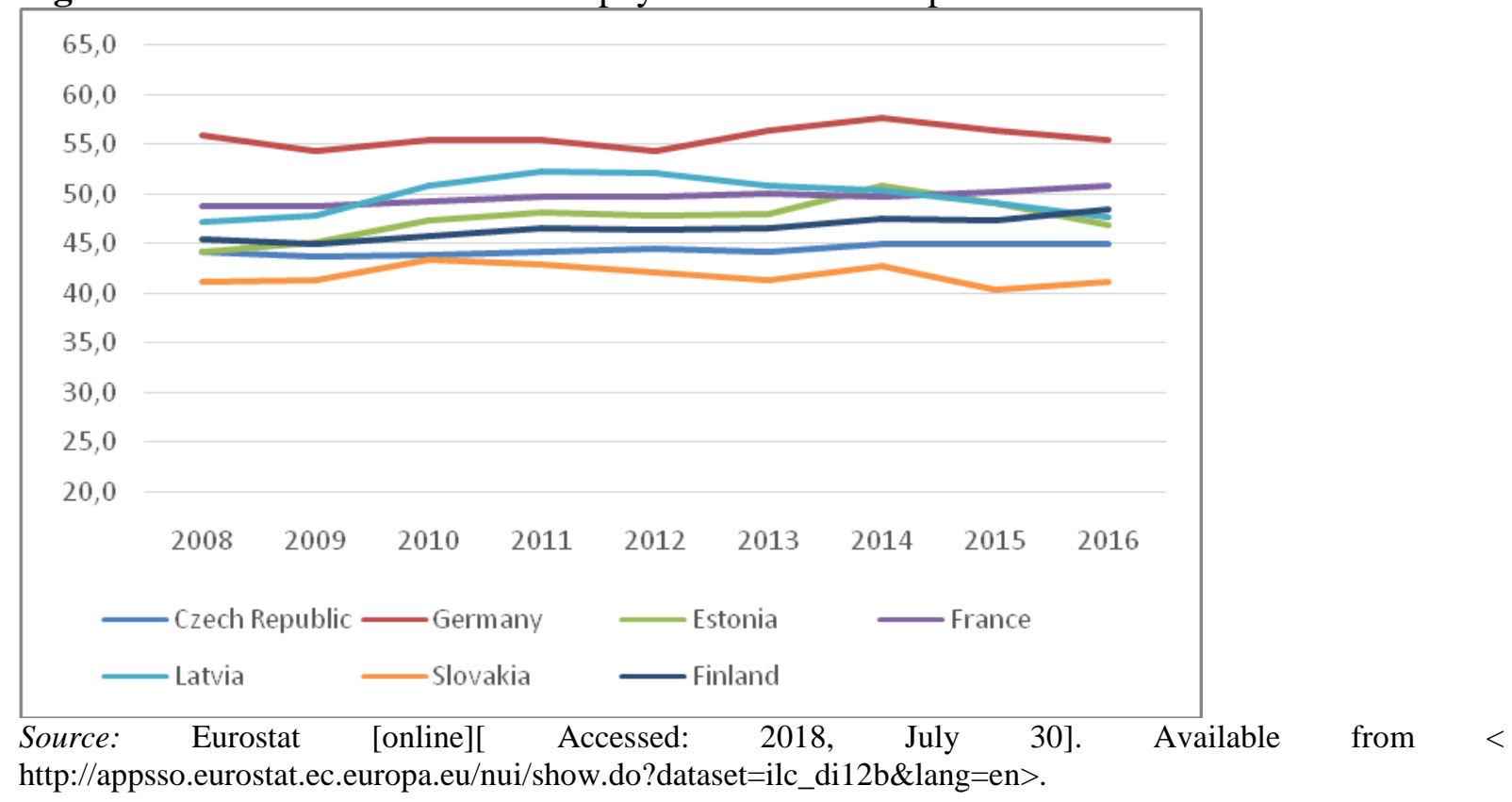




\subsection{Methodology}

Generally, the following classical methods are used: input data and the examination of indicators, the comparison of particular characteristics at the international level, deduction and synthesis for the purposes of the formulation of conclusions. For the purposes of achieving the main objective of the paper, the author uses the correlation analysis.

Thanks to the calculation of the correlation coefficients, the correlations between selected indicators of income inequality are studied. Correlation coefficients can take the value in the interval $\langle-1 ; 1\rangle$, whereas the positive or negative values signal the dependence direction. The absolute value expresses the strength of the dependence. The dependence can be studied as linear (the Pearson's correlation coefficient) or nonparametric (the Spearman's correlation coefficient).

The Pearson's correlation coefficient is defined (more Hindls, Hronová, Seger 2012) as

$$
r=\frac{\sum_{i=1}^{n}\left(x_{i}-\bar{x}\right)\left(y_{i}-\bar{y}\right)}{\sqrt{\sum_{i=1}^{n}\left(x_{i}-\bar{x}\right)^{2} \sum_{i=1}^{n}\left(y_{i}-\bar{y}\right)^{2}}}
$$

and the Spearman's correlation coefficient as

$$
\rho=\frac{6 \sum_{i}^{n}\left(p_{i}-q_{i}\right)^{2}}{n\left(n^{2}-1\right)}
$$

For the purposes of this paper, the correlation analysis is performed for the period 2008 2016 as a cross-sectional analysis.

\section{Results}

Firstly, we should focus on the relationships between selected indicators of income inequality within the European Union (S80/S20, the Gini index and the Gini index before a transfer), based on linear dependence. The following Table 1 shows us the results of the correlation analysis based on the Pearson's correlation coefficient. The number of observations was 28 for each year, that is, for each state of the European Union.

Table 1: The Pearson's correlation coefficients

\begin{tabular}{|l|l|l|l|l|l|l|l|l|l|}
\hline & 2008 & 2009 & 2010 & 2011 & 2012 & 2013 & 2014 & 2015 & 2016 \\
\hline S80/S20 and GINI & $0.969^{* *}$ & $0.967^{* *}$ & $0.972^{* *}$ & $0.971^{* *}$ & $0.964^{* * *}$ & $0.962^{* *}$ & $0.961^{* * *}$ & $0.963^{* *}$ & $0.966^{* *}$ \\
\hline S80/S20 and GINIbT & $0.463^{*}$ & 0.349 & $0.435^{*}$ & $0.407^{*}$ & $0.493^{* *}$ & $0.518^{* *}$ & $0.499^{* *}$ & $0.510^{* *}$ & $0.492^{* *}$ \\
\hline GINI and GINIbT & 0.455 & 0.311 & $0.424^{*}$ & $0.410^{*}$ & $0.496^{* *}$ & $0.515^{* *}$ & $0.483^{* *}$ & $0.553^{* *}$ & $0.529^{* *}$ \\
\hline
\end{tabular}

*Correlation is significant at the 0.05 level. ${ }^{* *}$ Correlation is significant at the 0.01 level.

Source: own calculation in SPSS.

Regarding the relationship between the coefficient S80/S20 and the Gini index, we can see the positive statistically significant relationship in all period. The values of the Pearson's correlation coefficient are higher than 0.9. There is a very strong linear dependency between those indicators of income inequality. Despite certain differences in the calculation, the explanatory value of income inequality in the studied countries is clearly visible. 
Focusing on the relationship between those indicators of income inequality and the Gini index before a transfer payment, we can see the values of the Pearson's correlation coefficient in the range of 0.311 and 0.553 . There are statistically significant values in most of the cases. There is a middle positive linear dependency between the indicators of income inequality and the Gini index before a transfer payment. This reflects the different use of transfer payments in reducing income inequality.

Analysing the nonparametric relationship of particular variables, the following Table 2 shows us the results of correlation analysis based on the Spearman's correlation coefficient. The number of observations was 28 as for the linear correlation.

Table 2: The Spearman's correlation coefficients

\begin{tabular}{|l|l|l|l|l|l|l|l|l|l|}
\hline & 2008 & 2009 & 2010 & 2011 & 2012 & 2013 & 2014 & 2015 & 2016 \\
\hline S80/S20 and GINI & $0.991^{* *}$ & $0.991^{* *}$ & $0.987^{* *}$ & $0.980^{* *}$ & $0.974^{* *}$ & $0.983^{* *}$ & $0.958^{* *}$ & $0.989^{* *}$ & $0.984^{* *}$ \\
\hline S80/S20 and GINIbT & $0.466^{*}$ & $0.466^{*}$ & $0.435^{*}$ & $0.500^{* *}$ & $0.569^{* *}$ & $0.524^{* *}$ & $0.606^{* *}$ & $0.630^{* *}$ & $0.583^{* *}$ \\
\hline GINI and GINIbT & $0.477^{*}$ & $0.477^{*}$ & $0.424^{*}$ & $0.461^{*}$ & $0.543^{* *}$ & $0.503^{* *}$ & $0.524^{* *}$ & $0.598^{* *}$ & $0.546^{* *}$ \\
\hline
\end{tabular}

${ }^{*}$ Correlation is significant at the 0.05 level. ${ }^{* *}$ Correlation is significant at the 0.01 level.

Source: own calculation in SPSS.

Focusing on the Spearman's correlation coefficient and the relationship between the coefficient S80/S20 and the Gini index, the values of correlation coefficient are higher than in the case of the Pearson's correlation coefficient. It is in the range of 0.958 and 0.991 . The values are statistically significant in all period. There is a very strong positive statistically significant relationship between the indicators of income inequality.

Dealing with these two indicators and their relationship with the Gini index before a transfer payment, we can see similar but slightly higher values than in the case of the Pearson's correlation coefficient. All values are statistically significant. There is also middle positive nonparametric dependency.

Regarding the change of the Gini index before and after a transfer payment we can show table 3. The value in the table means how many percents is the Gini index from the value of the Gini index before transfer payments (the value before the transfer payments is in the calculation included as 100\%). The lower the change value is, the higher the percentage of redistribution through transfer payments in this country is. 
Table 3: The change of Gini index before and after transfer payment (\%)

\begin{tabular}{|l|r|r|r|r|r|r|r|r|r|}
\hline & 2008 & 2009 & 2010 & 2011 & 2012 & 2013 & 2014 & 2015 & 2016 \\
\hline Belgium & 57.3 & 56.7 & 57.2 & 55.8 & 55.6 & 55.0 & 54.4 & 54.6 & 53.9 \\
\hline Bulgaria & 72.2 & 72.0 & 71.1 & 72.8 & 70.7 & 72.1 & 69.7 & 71.7 & 71.4 \\
\hline Czech Republic & 56.0 & 57.4 & 56.8 & 57.1 & 56.0 & 55.8 & 55.8 & 55.7 & 55.9 \\
\hline Denmark & 54.1 & 45.7 & 52.4 & 52.4 & 51.8 & 52.1 & 52.2 & 53.0 & 54.6 \\
\hline Germany & 53.9 & 53.5 & 52.9 & 52.3 & 52.0 & 52.7 & 53.2 & 53.4 & 53.2 \\
\hline Estonia & 69.9 & 69.6 & 66.0 & 66.2 & 67.8 & 68.5 & 69.9 & 70.9 & 69.7 \\
\hline Ireland & 62.0 & 57.5 & 57.0 & 55.1 & 57.1 & 56.5 & 58.1 & 58.3 & 58.8 \\
\hline Greece & 68.0 & 67.0 & 67.0 & 64.5 & 60.3 & 55.8 & 56.6 & 56.3 & 56.5 \\
\hline Spain & 74.7 & 73.9 & 71.6 & 69.7 & 70.2 & 68.4 & 68.2 & 68.1 & 68.0 \\
\hline France & 61.1 & 61.4 & 60.6 & 62.0 & 61.2 & 60.2 & 58.8 & 58.2 & 57.7 \\
\hline Croatia & 64.8 & 64.2 & 65.6 & 63.2 & 62.3 & 62.7 & 62.1 & 61.7 & 61.4 \\
\hline Italy & 66.8 & 67.7 & 66.7 & 66.7 & 67.1 & 66.4 & 66.0 & 66.7 & 67.0 \\
\hline Cyprus & 74.4 & 74.9 & 71.0 & 69.0 & 70.6 & 71.8 & 74.5 & 67.3 & 63.9 \\
\hline Latvia & 79.4 & 78.3 & 70.5 & 67.1 & 68.5 & 69.3 & 70.6 & 72.1 & 72.5 \\
\hline Lithuania & 71.1 & 70.1 & 67.2 & 61.5 & 62.6 & 65.0 & 67.6 & 70.6 & 70.7 \\
\hline Luxembourg & 63.0 & 62.1 & 60.3 & 59.5 & 58.6 & 61.4 & 59.8 & 59.3 & 63.5 \\
\hline Hungary & 50.8 & 50.2 & 48.9 & 51.0 & 52.7 & 53.4 & 54.1 & 54.8 & 55.0 \\
\hline Malta & 67.5 & 67.0 & 67.0 & 64.3 & 63.5 & 63.7 & 62.8 & 63.3 & 63.8 \\
\hline Netherlands & 60.7 & 60.0 & 57.7 & 56.3 & 55.1 & 55.9 & 57.2 & 57.9 & 57.8 \\
\hline Austria & 59.8 & 58.8 & 59.1 & 57.6 & 58.6 & 57.4 & 57.7 & 57.1 & 57.5 \\
\hline Poland & 64.3 & 65.1 & 64.9 & 65.1 & 65.1 & 64.4 & 64.3 & 63.9 & 63.8 \\
\hline Portugal & 71.3 & 69.8 & 67.4 & 68.0 & 61.7 & 61.2 & 57.1 & 57.0 & 56.0 \\
\hline Romania & 65.6 & 63.9 & 63.0 & 62.7 & 64.3 & 65.0 & 65.8 & 70.3 & 65.1 \\
\hline Slovenia & 57.9 & 57.6 & 56.5 & 55.9 & 55.0 & 55.3 & 56.4 & 55.8 & 56.0 \\
\hline Slovakia & 57.7 & 60.0 & 59.8 & 59.9 & 60.1 & 58.6 & 61.0 & 58.7 & 59.0 \\
\hline Finland & 57.9 & 57.7 & 55.5 & 55.4 & 55.8 & 54.6 & 53.9 & 53.2 & 52.5 \\
\hline Sweden & 45.0 & 47.7 & 45.5 & 44.6 & 47.0 & 46.8 & 46.5 & 47.1 & 47.8 \\
\hline United Kingdom & 65.3 & 61.1 & 61.4 & 61.8 & 56.6 & 55.4 & 58.3 & 58.5 & 58.3 \\
\hline Sourc: & 6 & & $56 c 5$ & 2018 & & & 301. & $A v 21.5$ & \\
\hline
\end{tabular}

Source: Eurostat [online][ Accessed: 2018, July 30]. Available from <

https://ec.europa.eu/eurostat/data/database>, own calculation.

The Gini index change before and after the transfer of payments was the most significant in Sweden, a significant difference was also seen in Denmark. This confirms the strength of the welfare state in the Scandinavian countries, which is manifested by a high degree of redistribution. The least significant are values in Bulgaria, Spain, Cyprus, Latvia, and Lithuania. A large degree of redistribution is not a typical feature of economic policy in these countries.

There are significant changes in time in some countries. E.g. in Portugal, the change of the Gini index was from 71.3 in 2008 to 56.0 in 2016. This is a significant decrease in value. This reflects on the importance of transfer payments in time. The variation in the development of the change of the Gini index is also in Latvia. The changes of the Gini index have fluctuating character in this country.

In general, changes in the Gini index are not significant and, over time, their approach to redistribution does not change fundamentally.

\section{Discussion}

There are two basic indicators of income inequality - the Gini index and the coefficient S80/S20. As the results show, there is very strong dependence between those indicators. Both 
indicators can serve to describe income inequality in individual countries. Their ability to describe the system is almost the same.

Because of different social policy in countries of the European Union, the relationship between these indicators of income inequality and the Gini index before payment is a middle positive dependency. A transfer payment is different in more aspects. Bejakovic', Mrnjavac (2016) analysed the role of the tax system and the social security systems in reducing income inequality in Croatia and selected states of the European Union. They results confirm that different welfare systems and different social policies lead to various outcomes in changes of income inequality. The governments of the individual countries approach this topic with large differences.

An important classification of countries according to the concept of the social state was introduced by Esping and Andersen (1990). It divided the country into three basic groups: liberal (with a marginal role of the family and the state and a central role of the market), the social-democratic (with a marginal role of the family and the market, and the central role of the state) and conservative (with a marginal role of the market, a supporting role of the state and the central role of the family). The role of the social state is an important factor of the parameters of a transfer payment in the social policy. The result shows that Scandinavian states (Sweden, Denmark and Finland - exception in the beginning of the time period) are social-democratic states with the central role of the state and France and Austria are typical representatives of the conservative states.

Noikokyrakis, Sarafis (2018) classified the social policy of European Union 15 countries into four categories. These categories are the social democratic, the conservative-corporative, the liberal and the Southern European model. The classification by Esping and Andersen is supplemented by the Southern European model. This is confirmed by results. Southern European countries have a lower rate of the redistribution, especially Spain and Cyprus.

Gonthier (2015), in his study, focused on the development of benefits and the role of the state from 1980 to 2008. He pointed out the fact that most of the EU countries have a relatively well-developed level of the social benefits system, and that the role of the state slightly increased in this period. The importance of the state in the area of income inequality associating with tax redistribution and social policy is confirmed by results in this paper. The value of the Gini index changes after a transfer payment almost half the value.

\section{Conclusion}

Income inequality is an integral part of the company and as such cannot be considered a modern-day problem. The current systems are trying to mitigate them. Redistribution takes place both through tax systems and by using systems of social policy in the form of transfer payments. The degree of redistribution in countries differs and is largely limited by both the historical practice, and the economic capabilities of the country. The European Union is a community of diverse countries. Therefore, the setting of their social policy due to the redistribution of income in society is also quite different.

The aim of the paper was to find out whether there are mutual links between selected indicators of income inequality and how they change after the inclusion of transfer payments. Because there is very strong dependence between the Gini index and the coefficient S80/S20, we can use both indicators to describe the situation of income inequality. The development of this indicator is almost the same. There is a middle positive linear dependency between the 
indicators of income inequality and Gini index before a transfer payment. This reflects the different use of transfer payments influencing income inequality in European countries. The results confirm the concernment of state in the area of income inequality because the value of the Gini index is changed very distinctly after a transfer payment. The redistribution of income by the state is important for maintaining a low level of income inequality in European countries.

\section{References}

[1] ADRIAN RISSO, W. and E. J. SANCHEZ CARRERA, 2018. On the impact of innovation and inequality in economic growth. Economics of Innovation and New Technology. 28(1), p. 64-81. ISSN 1043-8599.

[2] AKBULUT, H. and M. C. GURAN, 2015. The Effect of Transfer Payments on Economic Growth: Panel Data Analysis for Developing Countries for 1990-2011. Maliye Dergisi. 168, p. 134-153. ISSN 1300-1323.

[3] BEJAKOVIC', P. and Ž. MRNJAVAC, 2016. The role of the tax system and social security transfers in reducing income inequality: The case of the republic of Croatia. Ekonomski Pregled. 67(5), p. 399-417. ISSN 1848-9494.

[4] ESPING-ANDERSEN, G., 1990. The Three Words of Welfare Capitalism. New Jersey: Princeton University Press. ISBN 0-691-02857-5.

[5] EUROSTAT: DATABASE [online] [Accessed: 2018, July 30]. Available from <https://ec.europa.eu/eurostat/data/database>.

[6] GONTHIEL, F., 2015. The rise of interventionism in the European Union and its social foundations. An analysis of economic attitudes between 1990 and 2008. Revue Francaise de Sociologie. 56(1), p. 7-46. ISSN 0035-2969.

[7] HINDLS, R., S. HRONOVÁ a J. SEGER, 2012. Statistika pro ekonomy. Praha: Professional Publishing. ISBN 978-80-869-4643-6.

[8] HRDLIČKOVÁ, Z., 2006. Vliv sociální politiky na konkurenceschopnost české ekonomiky. Centrum výzkumu konkurenčni schopnosti české ekonomiky. Working paper 8/2006. ISSN 1801-4496.

[9] KVÍČCLOVÁ, J., 2014. Ekonomické faktory ovlivňující př́ijmovou nerovnost ve společnosti. In Conference Proccedings of MEKON 2014, Selected Papers. Ostrava: VŠB-TUO, p. 60-70. ISBN 978-80-248-3316-3.

[10] MALÁ, Z. a G. ČERVENÁ, 2012. Dekompoziční analýza př́ijmové nerovnosti v České republice. Ekonomická revue. 5(1), p. 5-14. ISSN 1212-3951.

[11] MATSAGANIS, M. and CH. LEVENTI, 2013. The Distributional Impact of the Greek Crisis in 2010. Fiscal Studies. 34(1), p. 83-108. ISSN 1475-5890.

[12] NOIKOKYRAKIS, G. and P. SARAFIS, 2018. Social protection and the challenges of the European Welfare State. Archives of Hellenis Medicine. 35(4), p. 464-471. ISSN 1989-5216.

[13] ROCHOVSKÁ, A. a L. NÁMEŠNÝ, 2011. Chudoba a pracujúci chudobní na Slovensku-analýza údajov EU SILC. Geographia Cassoviensis . 5 (2), p. 103-117. ISSN 1337-6748. 
[14] TIRUNEH, W. et al., 2009. Vývoj a perspektívy svetovej ekonomiky. Globálna finančná a hospodárska kríza. Príčiny - náklady - východiská. Bratislava: Ekonomický ústav SAV. ISBN 978-80-7144-175-5.

[15] VEČERNÍK, J., 2012. Subjektivní indikátory blahobytu: př́istupy, měření, data. Politická ekonomie. 60(3), p. 291-308. ISSN 0032-3233.

[16] VÍTEK, L. and J. PAVEL, 2012. Effect of Changes in Taxes and Benefits on Redistribution in the Czech Republic.In Modern and current trends in the public sector research. Brno: MU, p. 155-163. ISBN 978-80-210-5822-4.

[17] ŽELINSKÝ, T. a I. PAUHOFOVÁ, 2012. Vývoj príjmových nerovností v Európskej únii. Paradigmy budúcich zmien v 21. storočí. Infraštruktúra spoločnosti, infraštruktúra človeka, kontrolovaná spoločnost'. Bratislava: EU SAV, p. 116-126. ISBN 978-80-7144198-4. 